\title{
Applications with semipermeable membranes for humidity recovery in HVAC systems
}

Ralph Krause $^{\text {(a) }}$, Hannes Rosenbaum ${ }^{(\text {a) }}$, Ralf Herzog $^{\text {(a) }}$

(a) Institute of Air Handling and Refrigeration

Dresden, 01309, Germany, klima@,ilkdresden.de

\begin{abstract}
Both the sensible heat recovery and the combined heat and humidity recovery are state of the art. Of particular importance is the humidity recovery in winter season. The transfer of water vapor from the humidity-laden exhaust air to the very dry fresh air is very important for a good room air quality.

However, all systems established on the market require that supply and exhaust air streams crosses within the device. Practical enthalpy recovery systems for plant concepts with local separation of supply and exhaust air are not available on the market until now.

In order to close this gap, the ILK Dresden works on a R\&D project. The objective is the development of a textile heat exchanger, which - integrated into circulatory composite systems - can transmit not only sensible heat but also humidity between spatially separated air streams. The functional principle is based on a liquid sorption process via semipermeable membranes.

The current state of the development will be presented. Furthermore an outlook is given how it is intended to proceed in the project in further steps.

Keywords: semipermeable membrane, liquid sorption, humidity recovery, hvac, textile heat exchangers, hygiene, energy efficiency
\end{abstract}

\section{INTRODUCTION}

Research and development on applications with membranes is an important field of activities at ILK Dresden for more than ten years. The first idea was to eliminate the application of open water circulation systems in HVAC systems in order to improve hygienic conditions because the availability of water is the requirement for all unwanted organic growth, as well as to prevent corrosion damage. [1] The first investigations figured out that the technology of dehumidification by means of semipermeable membranes works quite well. [2] However, the technical problems rose up, e.g how to fix the membranes in the airstream or how to tighten it against the pressure drop. Therefore different applications were investigated regarding different ways how to attach the membranes on a textile basis. [3] Furthermore, an ongoing research project focuses on improved applications with materials with longterm stability. This paper provides an overview on the most important results and presents an outlook on the further work on this topic. 


\section{SEMIPERMAEBLE MEMBRANES FOR HUMIDITY RECOVERY}

\section{Motivation}

Thermal comfort in rooms requires not only cooling but also dehumidification of outdoor air. Dehumidification by temperature falling below the dew point temperature takes a huge amount of energy (latent cooling) [4]. The share on the total cooling capacity of a chiller is usually more than $50 \%$. Therefore, common cooling processes uses compressors driven by electrical energy. In a study, focused on Germany only, a total energy amount for cooling purposes in HVAC systems was calculated to $3.97 \mathrm{e} 9 \mathrm{kWh} /$ year [5]. This is equivalent to nearly $3 \mathrm{e} 9 \mathrm{~kg}$ $\mathrm{CO}_{2} /$ year. With respect to this background a high potential of energy saving by using liquid sorption processes rise up due to the fact that simply heat can be used for dehumidification. This can be heat based on renewable energy or waste heat from other processes. Figure 1 shows the share of sensitive and latent cooling. It provides a very good impression of the energy saving potential [6] [7].

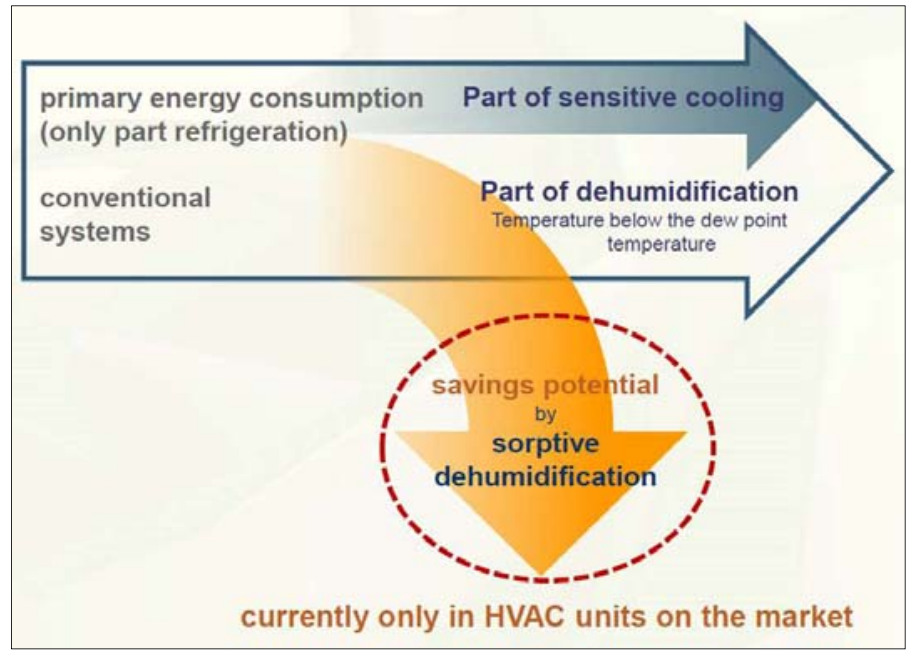

Figure 1. Cooling demand for air conditioning systems

\section{State of the art}

Liquid desiccant is currently used in some HVAC systems on the market [8] [9]. A well-known schematic example is presented in Figure 2. The liquid desiccant causes the absorption of water vapour. Disadvantages of this open system are corrosion issues because of the brine aerosols and the impossibility to use this technology in decentral ACs. These may be some reasons for a very low market share. 


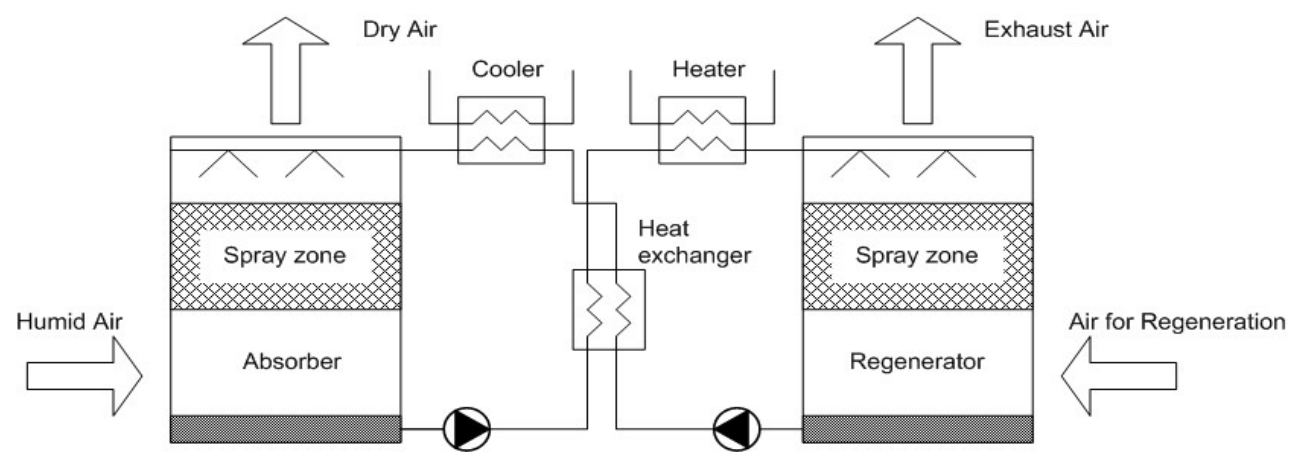

Figure 2. Example of a current liquid cooing system on the market, kathabarsystem

\section{General functionality of membranes in HVAC systems}

The schematic process for heat- and mass transfer is presented in Figure 3. The membrane separates the air stream and the liquid desiccant. Only the water vapour is capable of permeating the membrane. The transport mechanism forces the vapour to move from the high fluid with the high partial water vapour pressure (air) to the fluid with lower partial pressure (desiccant). The result is the dehumidification of the air stream while the brine will be diluted. A prototype of a membrane heat exchanger is presented in the upper left of Figure 4. Responding measurement results are presented additionally in the same figure.

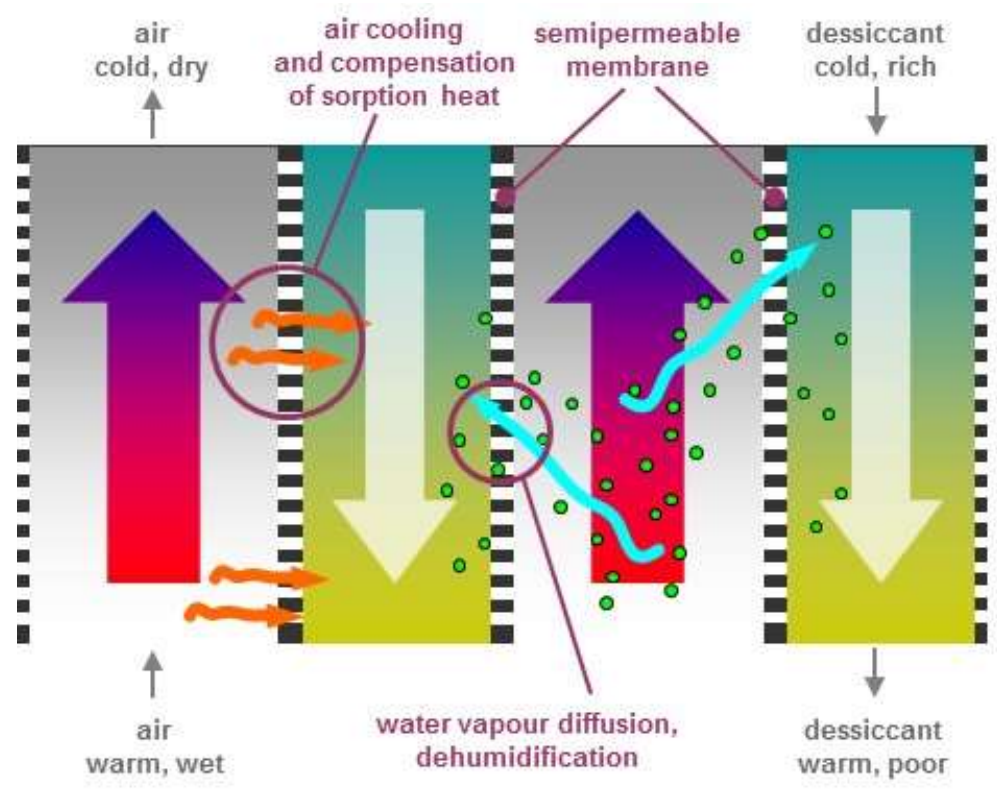

Figure 3. Schematical illustration of desorption process with semipermeable membranes 


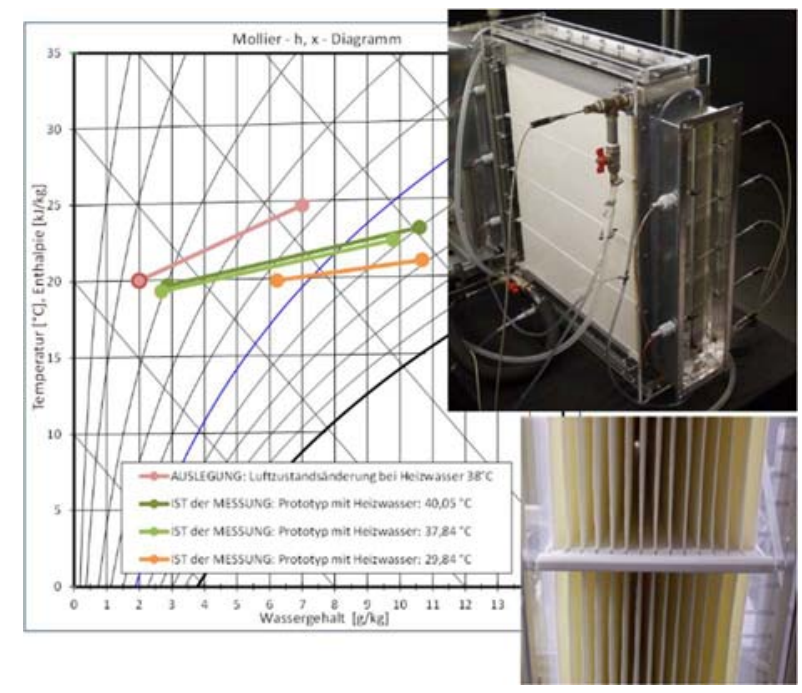

Figure 4. Prototype of a membrane heat exchanger developed by ILK Dresden

\section{New Applications with membranes}

Since 2006 the ILK Dresden has been working on different research and development projects based on applications with semipermeable membranes. The aim over all the projects was to separate the air stream and fluid by the membrane to prevent any liquid pouring the air duct. The most important results are:

- provide high hygiene requirements because of condensate free dehumidification

- increase the energy efficiency by using simply heat for dehumidification (e.g. solar heat or waste heat)

- enable the possibility for enthalpy recovery systems with local separation of supply and exhaust air streams

Until now some new applications were developed by ILK Dresden. The most important applications are:

- membrane heat and mass exchangers with dehumidification and humidification function [10] [11]

- membrane based cooling ceiling [12] [13] [14]

- application for regeneration process of the desiccant liquid based on membranes [3]

- $\quad$ enthalpy recovery between locally separated air streams [15]

All the applications were tested in the lab of ILK Dresden. The general functions were proved. For the commercial use there are same further steps necessary. Especially the manufacturing and the assembling process of the membranes are important for commercial success. 
Also issues of the hydraulic system in the building has to be considered. Furthermore demands on hygiene requirements and long time stability are important for future commercial use.

\section{CONCLUSIONS}

In the last years the ILK Dresden has developed different applications for HVAC systems using membranes for dehumidification or humidification. All the applications has been tested successfully in the lab. Because of the special properties of the liquid desiccant renewable energy can be used for the process. This gives the possibility to save a huge amount of energy because of the possibility to dry air without falling below the dew point temperature.

However there are some tasks to do in the future to improve membrane based applications in AC systems. Currently the ILK Dresden is working on issues like long time stability, material compatibility or efficient assembling processes.

It can be assumed that the number of membrane based applications will be increase in the next years. It will also increase the energy efficiency and may afford a share to solve the environmental problems.

\section{ACKNOWLEDGEMENTS}

This work has been supported by the Federal Ministry for Economic Affairs and Energy of the Federal Republic of Germany under Contracts no. MF 180112.

Supported by:

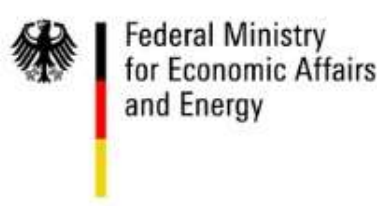

on the basis of a decision by the German Bundestag

\section{REFERENCES}

1. VDI Gesellschaft Technische Gebäudeausrüstung:

VDI 6022 - Raumlufttechnik, Raumluftqualität, Hygieneanforderungen an raumlufttechnische Anlagen. Beuth-Verlag, 2018

2. Rosenbaum, H.:

Der Grundstein ist gelegt... Erhebliches Einsparpotential durch

Membranbasierte Raumklimatisierung. Sanitär+Heizungstechnik 7/2011

3. Rosenbaum, H.:

Membranbasierte Raumklima $\neg$ tisierung - dezentrale sorptions $\neg$ gestützte Klimatisierung, KI Kälte Luft Klimatechnik 04/2012 
4. Günther Mertz

6.200 Milliarden Kilowattstunden Klima-Strom - Studie der IEA zur weltweiten Raum- und Gewerbeklimatechnik im Jahr 2050, BTGA Almanach 2019, Strobl Verlag GmbH \& Co.KG

5. Beck,E (2000):

Energieverbrauch,-einsparpotential und-Grenzwerte von Lüftungsanlagen. Kassel: Universität Kassel, 2000

6. Mai, R.:

DEC-Anlagen im Umfeld der Energiewende, VDI-Fachkonferenz «Wärmeeinsatz zum Kühlen und Klimatisieren». Berlin 05/2013

7. Simader; Rakos:

Klimatisierung, Kühlung und Klimaschutz: Technologien, Wirtschaftlichkeit und CO2-Reduktionspotentiale. Materialband Austrian Energy Agency; Wien 2005; (Fallbeispiel DEC-Anlage Seite 74)

8. Hauer; Lävemann:

Möglichkeiten offener Sorptionsspeicher zum Heizen, Klimatisieren und Entfeuchten. Veröffentlichung des ZAE Bayern zum Thema Thermochemische Speicher, Herausgegeben vom BINE- Informationsdienst 2006

9. Lävemann; Peltzer: «Offenes Sorptionssystem zur solaren Klimatisierung eines Gebäudes in Singapur». ZAE-Bayern, L-DCS Technology GmbH; IHK-Arbeitskreis Energieeffizienz; Garching 2006

10. Rosenbaum, H.:

Hygrisch aktiver Lufterhitzer - hygienische und energieeffiziente Luftbefeuchtung über Membranen, Deutsche Kälte- und Klima Tagung, Dresden, 18.-20.11.2015

11. Rosenbaum, H.:

Membranbasierte Raumklimatisierung“, Die KÄLTE + Klimatechnik $12 / 2011$

12. Rosenbaum, H.:

Flüssigsorption mit Membran-Kühldecke - Voraussetzungen, Einsatzpotential und -grenzen; tab - Das Fachmedium der TGA-Branche, $05 / 2014$ 
13. Rosenbaum, H.:

Membran-Kühldecke mit kondensatfreier Luftentfeuchtung -

Messtechnische Analyse einer ersten Pilotanwendung dezen $\neg$ traler

Flüssigsorptionsprozesse; KI Kälte Luft Klimatechnik, März 2014

14. Rosenbaum, H.:

Sorptionsgestützte Klimatisierung und Membran-Kühldecken, BTGAAlmanach 2013, Strobl Verlag GmbH \& Co.KG

15. Rosenbaum, H.:

Einsatz textiler Materialien zum Feuchtetransport - Luftreinhaltung bei der thermischen Luftbehandlung nach dem Filter. 12. Dresdner Kolloquium zur Luftreinhaltung; Dresden 09/2019

16. Rosenbaum; Herfert

Prima Klima ohne Haevy-Metal-Technik - Textile Verbundsys $\neg$ teme mit Abstandstextilien für die Raumklimatisierung, Kettenwirk-Praxis

Textilinformationen, Karl Mayer, 01/2013 